\title{
2. \\ DRUŠTVENA RASLOJAVANJA U \\ MEĐURATNOM SPLITU: \\ JEDNA POVIJEST ODOZDO
}

\section{Tomislav Branđolica}

UDK: 316.343(497.5 Split)“1918/1941“

Pregledni rad

Sažetak: U radu se analiziraju teme iz povijesti splitskih društvenih slojeva u razdoblju između dva svjetska rata, vremenu velikog splitskog gospodarskog i demografskog rasta i preobražaja. Perspektiva koja se pritom koristi je povijest odozdo te teorijske i historiografske postavke Erica Hobsbawma. Kroz analizu postojeće literature, primjera iz beletristike, reproduciranih razgovora sa svjedocima vremena i suvremenih novinskih izvora pristupa se povijesti zanatskog, težačkog i radničkog sloja Splita, kao i njihovim svakodnevnim navikama i običajima. Pritom se prati njihove radne svakodnevice i dokolicu. Kao važan dio urbane dokolice radnih slojeva promatra se i sport, na prvom mjestu nogomet, koji je bio čimbenik izgradnje urbanog i socijalnog identiteta. Predstavljaju se i neki elementi političkog djelovanja ovih slojeva, ali i šireg društvenog angažmana onih slojeva koji nisu neposredno javno politički djelovali. Također je valoriziran i neizostavan doprinos splitskog građanstva kao vladajuće klase.

Ključne riječi: Split, međuratna povijest, društveni slojevi, radništvo, sport, povijest odozdo, Eric Hobsbawm

ako je moguće obraditi društvene slojeve u međuratnom Splitu odozdo? Kad bi se definirali i posložili svi društveni slojevi - činili bi jednu kompleksno ustrojenu piramidu $\checkmark$ podijeljenu po sektorima posjedovanja socijalnog i ekonomskog kapitala. Perspektiva ovog rada je povijest odozdo jer se ispitivanjem stanja u nižim društvenim slojevima nastoji doći do odgovora koji objašnjavaju dalekosežne društvene i ekonomske promjene u međuratnom Splitu. Riječ je, dakle, o pristupu history from the bottom up. Za naše potrebe ovaj termin posuđujemo od njegovih najvažnijih historiografskih pronositelja, Erica Hobsbawma i Edwarda Palmera Thompsona. Usto ćemo nastojati slijediti Hobsbawmovu misao da je „povijest odozdo poput stare brazde pluga koju je izbrisalo vrijeme i koja je nestala zajedno sa svojim oračima prije nekoliko stoljeća. No, svakom je fotografu poznato da se pod određenim kutom i određenom sjenom vide davno zaboravljene i danas skrivene brazde. "1 Upra-

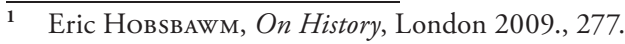


vo se takvoj snimci splitskog međuratnog društva ovdje želimo približiti. Još se ponegdje za opis ovog pristupa koriste i izrazi grassroots history ${ }^{2}$ ili history of the inarticulate. ${ }^{3}$ Direktan prijevod na hrvatski bio bi nespretan, ali bitno je znati da se radi o historiji onih koji su prolaskom vremena možda izgubili svoj glas, svog zagovornika u profesionalnoj historiografskoj areni. Riječ je o onima koji danas više nisu u tolikoj mjeri prisutni u kolektivnoj svijesti o prošlosti jer su izgubili svoju ekonomsku osnovu u društvu. Gubitak takvog oslonca može djelovati pogubno po identitet velikog dijela društva te je stoga pristup karakterističan za spomenuta dva engleska povjesničara primjenjiv i u okružju splitske povijesti. Specifično splitska historiografija ne oskudijeva širinom doprinosa. Međuratna povijest Splita, društvena i gospodarska, od 1960-ih godina nadalje prisutna je u profesionalnoj historiografiji već od početka djelovanja institucija poput Instituta za historiju radničkog pokreta Dalmacije, osnovanog s ciljem proučavanja doprinosa splitske radničke klase razvoju radničkog pokreta i kasnijoj Narodnooslobodilačkoj borbi. Taj je institut izdavao svoj Zbornik u kojem je nekoliko istraživača - među kojima je najpoznatiji Drago Gizdić - objavljivalo svoje priloge. Nezaobilazne radove iste tematike, kao i članke o gospodarskoj povijesti Splita, od druge polovice sedamdesetih do kraja devedesetih, objavljivao je Tonći Šitin. Uz važne doprinose koje su s historiografske strane dali istraživači poput Šitina do Zdravke Jelaske Marijan u najnovije vrijeme, mora se istaknuti važan doprinos publicistike i memoaristike. U toj kategoriji spominjemo Branislava Radicu i njegovu knjigu Novi Split: monografija grada Splita od 1918-1931. te Anatolija Kudrjavceva, koji je u svojoj knjizi Ča je pusta Londra... ispisao razvedenu i sveobuhvatnu posvetu međuratnom splitskom društvu. Nužno je spomenuti literarnu memorijalizaciju međuratnog Splita iz pera Miljenka Smoje ili esejističke definicije splitskog iskustva Bogdana Radice. Povjesničar umjetnosti Duško Kečkemet također je u svojoj dugoj karijeri napisao nekoliko djela u kojima Split između dva svjetska rata promatra $s$ jedne strane kao kulturno središte u stvaranju i kretanju prema punoj snazi, a s druge strane kao subjekt koji prolazi kroz višestruke društvene i gospodarske promjene.

Pri inicijalnom povijesnom pregledu ono što nas najčešće zanima demografski su pokazatelji. Kretanje broja stanovnika slijedilo je ovaj tempo: 1910. godine u gradu živi oko 21000 stanovnika. Godine 1921. Split ima oko 25000 stanovnika. U idućih deset godina broj raste za daljnjih 10000 stanovnika, da bi grad „prema općinskim podacima na kraju 1940. brojio 46000 stanovnika“. ${ }^{4}$ Kao detalj koji u prvom redu ukazuje na prirodni prirast, usmjeravamo se na okružje Veli Varoš, zbijeni volumen u kojem je svaka prostorna promjena vrlo važna. Prema popisu iz 1921. imao je 5379 stanovnika, a deset godina kasnije $7372 .{ }^{5}$ Broj kuća porastao je sa 687 u 1913. ${ }^{6}$ na 753 1931. godine. ${ }^{7}$ Udvostručen broj stanovnika u promatranom razdoblju signalizira bitnu činjenicu: privlačna sila split-

\footnotetext{
Isto, 266.

3 David Brody, „The Old Labor History and the New: In Search of an American Working Class“, The Labor History Reader (ur. Daniel J. Leab), Champaign 1985., 7.

Zdravka Jelaska Marijan, Grad i ljudi: Split 1918.-1941., Zagreb 2009., 25.

Branislav Radica, Novi Split: monografija grada Splita od 1918-1930 godine, Split 1931., 99.

Anita Ercegović, Pučka arhitektura starih splitskih predgrada, Split 2002., 60.

7 B. Radica, Novi Split, 100.
} 
skog centra u kratkom periodu pretvorila je ovaj grad u motor razvoja Dalmacije, u daleko većoj mjeri nego što je to bio slučaj ranije. Prirodni prirast u ovom slučaju zauzima drugo mjesto pred važnosti migracijskih tendencija bliže i šire dalmatinske okolice, a tim migracijskim tendencijama pribraja se na početku 1920-ih i nezanemariv broj doseljenika s novih talijanskih teritorijalnih stečevina. Između njih ističe se i obitelj Vladana Desnice, koja je nakon pripajanja Zadra Italiji došla živjeti i raditi u Splitu. Razvoj Splita u prvih deset poratnih godina Bogdan Radica je personalizirao u ličnosti načelnika dr. Ive Tartaglie, koji je prema njemu, „Split izdigao iz sitnog ali dragog nam provincijalizma i kampanilizma u grad jačih dimenzija i snažnijih mogućnosti, imajući protiv sebe sve i svakoga“" .8 Solidan dio splitske historiografske produkcije nakon 1990. godine Radičinom zaključku daje za pravo, iako i ove ocjene, objektivno revizionističke i intonirane u naglašeno nostalgičnom tonu, ${ }^{9}$ mogu biti podložne najraznovrsnijim daljnjim promišljanjima. ${ }^{10}$

Objašnjenja koja bi historiografija u slučaju ovog važnog regionalnog središta trebala nuditi valja temeljiti na objasnidbenim strategijama koje pokazuju osjećaj za aspekte socijalne, kulturne i intelektualne historije, uz priznavanje uloge događajnice i potrebu rekonstrukcije uloge pojedinca u njoj, ali uz istovremeno odmicanje od optike isključivog prikazivanja povijesti kroz djelovanje velikana (Great Man theory). Dok ova ista Great Man theory u posljednjih nekoliko desetljeća postaje sve više neraskidivo vezana uz hrvatsku historiografiju na nacionalnoj razini, potreba za takvim modelima na regionalnim i urbanim razinama proučavanja u pravilu neće nuditi zadovoljavajuće odgovore na istraživačka pitanja.

U povratku s teorijskih pitanja, pitamo se kakve su posljedice sve ove promjene u broju stanovnika imale na društveno raslojavanje? Popisne 1931. godine 22,06\% stanovništva splitske općine živjelo je od poljoprivrede i ribarstva. Naglašavamo, postupno sve više od ribarstva nego od poljoprivrede, koju je od 1926. godine nadalje potresala kriza. U obrtu i industriji radilo je $26,53 \%$ stanovništva, u javnim službama radilo je $15,43 \%$, prometom se bavilo $9,74 \%$, trgovinom oko $7,19 \%$ pučanstva, a novčarstvom $1,64 \%$ građana. ${ }^{11}$ Ovi iznosi pružaju nam uvid na makrorazini. Dalje se pitamo kako su izgledali odnosi među ovdje navedenim slojevima? Svaki pojedini splitski sloj, obzirom da je živio u kulturi koja je znala investirati u moć pisane riječi, imao je svoje zastupnike u medijskoj areni. Zainteresirani radnički slojevi mogli su potvrdu svojih stavova tražiti u publikacijama poput Radnič̌kog odjeka: lista radnika i siromašnih seljaka (izlazio tokom 1928. kao podrška izbornoj listi Republikanskog saveza radnika i seljaka), Radničkom pravu (iz 1927. godine, samoprozvanom „glasnik(u) kršćansko socijalističkih sindikata“ ${ }^{12}$ sa željom da „po Kristovim načelima oslo-

8 Bogdan Radica, Vječni Split, Zagreb 2002., 145.

9 Vidjeti, primjerice, biografiju Tartaglie iz pera njegove unuke: Norka Machiedo Mladinić, Životni put Ive Tartaglie, Split 2001.

10 Tu podlogu mogu činiti razmišljanja koja su se sporadično pojavljivala u tisku. Prenosimo jednu ocjenu vladavine Tartaglie: „Kod splitske buržoazije Dr. Tartaglia uživa glas najboljeg načelnika što ga je dosad Split imao. O njemu se govori samo u superlativima. (...) Radnička klasa bila je jedina koja je u Dru. Tartagli gledala jednog kapitalističkog eksponenta, čija je svaka kretnja sračunata na dopadanje kapitalističkim, režimskim i vojnim krugovima, dok je za nj i njegovu okolinu sirotinja postojala samo u toliko koliko je trebalo da se iz nje cijede milijuni i troše na stvari koje sa njom ne samo što nemaju ništa zajedničkog, već su često protiv nje direktno uperene.“ „Načelnikovanje dr.a Tartaglie u svjetlu radničke kritike“, Radnički odjek: list radnika i siromašnih seljaka, br. 16, 3. 11. 1928., 1.

11 Z. Jelaska Marijan, Grad i ljudi, Zagreb 2009., 50. 
bodi radnika ${ }^{\text {“13) }}$ ili Hrvatskom pomorcu (izlazio na samom kraju tridesetih, a stavljao je jak naglasak na neraskidivu vezu između HSS-a, pomoraca, radnika i njihovog zajedničkog vođe Mačeka). Posebne interesne skupine također su povremeno nalazile prostor u medijima - početkom dvadesetih i krajem tridesetih izlazili su listovi Stanar, posvećeni problemima života splitskih podstanara. Isključiv pogled odozdo oduzeo bi nam mogućnost da uočimo kako je i gradska buržoazija pokretala svoja glasila. Tako je kratko izlazio Glas bankovnog činovništva u Dalmaciji kao i Obrtnički vijesnik. Nešto je dulji rok trajanja imala Privrednička riječ, koja je u neskladu s podnaslovom „Tjednik za promicanje interesa trgovačko-obrtničkog staleža" uglavnom nastojala bilježiti gospodarske i društvene činjenice. Što je zajedničko ovim medijskim pothvatima? Nijedan od njih nije trajao dulje od nekoliko godina, publikacije su u pravilu imale životni vijek od nekoliko mjeseci. Svjedočanstvo je to o dinamičnoj i nesigurnoj stvarnosti splitskog tržišta, njegovom skokovitom razvoju kao i stvarnim političkim poteškoćama koje je izlaženje jednog lista moglo prouzrokovati.

Za društvenu svijest pojedinih slojeva ipak nisu bili dovoljni niti potrebni časopisi ili listovi. Ona se - posebno kod obrtnika i zanatlija - formirala i transformirala kroz više generacija i prenosila s koljena na koljeno. Same zanatske radnje su u gradu, prema riječima Kudrjavceva, „nasljeđivale davno stečeni značaj“, ${ }^{14}$ što upućuje na zaključak o društvenom statusu pojedinih slojeva i usluga koje su pružale. Osim toga, Kudrjavcev je prema iščitavanju bogatih zapisa o splitskoj povijesti ponudio tezu:

(...) da su „zanačije“ bili pokretači i sudionici svih gradskih zgoda, i da su se najvažnije stvari zbivale i začinjale upravo u njihovim radnjama. Razgovori u kavanama imali su također društvenu važnost, ali njihova je intonacija bila dokoličarska. Ono, pak, o čemu se govorilo među zanatlijama kao da je redovito bilo vezano uz neki radni motiv, ili uz neku predstojeću promjenu o kojoj se odlučuje. ${ }^{15}$

Upravo je pokretačka snaga obrtničkog i zanatlijskog sloja bitan moment koji svjedoči o kontinuitetima u njihovim svjetonazorima, naslijeđenima iz prethodnih desetljeća. Što se pritom nužno mijenja u međuraću? Mentalni okviri ostaju na mjestu, ali organizacijski okviri - bilo pod političkim patronatom ili zbog čiste društveno-ekonomske logike stubokom se mijenjaju. Poruka iz prvog broja Obrtničkog vijesnika zorno svjedoči o novim pravilima organiziranja:

Glavna snaga i moć jednog pokreta, bio taj politički, kulturni ili socijalni, uvjetovani su jakom i dobro provedenom organizacijom. Naročito se potreba organizacije osjeća danas kad se između ljudi sukobljuju u najdrastičnijim formama mračne sile neobuzdanog instinkta. ${ }^{16}$

Tada dolazimo i do bolnog klasnog momenta za obrtnike: „Nadasve je žalosna jedna činjenica (...), da su radnici kud i kamo bolje organizovani od svojih poslodavaca, i da, jedino svojim jakom organizacijama imaju da zahvale većinu svojih uspjeha. ${ }^{\text {"17 }}$ Obrtnici

12 „12. III 1927.“, Radničko pravo: glasilo Glavnog strukovnog saveza, br. 1, 12. 3. 1927., 1.

13 „Što hoćemo?", Radničko pravo: glasilo Glavnog strukovnog saveza, br. 1, 12. 3. 1927., 1.

14 Anatolij KudrJavcev, Upotrazi za izgubljenim Mediteranom, Split 2001., 58.

15 Isto.

16 „Za zajedničku saradnju dalmatinskih obrtnika“, Obrtnički vijesnik, br. 2, 23. 10. 1923., 1. 
su učili prolaskom vremena, pa je došlo, između ostalog, i do akcije 1931. godine kada su se postolari, čizmari i opančari suprotstavili dolasku poslovnica Bate u grad..$^{18}$ Razvoj obrtništva i zanatstva u međuratnom Splitu pratio je u stopu šire gospodarske trendove u gradu, ali je za pretpostaviti da ih je višestruko i naglašavao. Prema Branislavu Radici, broj radnja (čiji rast vidimo u donjoj tablici) „u razmjeru prema broju pučanstva, ukazuje se velikim, a to je stoga što ima mnogo obrta bez jačeg privrednog značenja među slobodnim obrtima“. 19

\begin{tabular}{|l|l|l|l|}
\cline { 2 - 4 } \multicolumn{1}{c|}{} & $\mathbf{1 9 1 9 .}$ & $\mathbf{1 9 2 8 .}$ & $\mathbf{1 9 3 0 .}$ \\
\hline \hline TRGOVAČKE RADNJE & 2801 & 4181 & 4442 \\
\hline ZANATSKE RADNJE & 1232 & 1740 & 1880 \\
\hline INDUSTRIJSKE RADNJE & 30 & 122 & 152 \\
\hline
\end{tabular}

Tablica 1. Rast bez pokrića? Kretanje broja trgovačkih, zanatskih i industrijskih radnji u Splitskom srezu ${ }^{20}$

Razmatranje odnosa obrtničkog i težačkog sloja također nudi neke zanimljive uvide u klasnu samopercepciju splitskih društvenih slojeva. Perislav Petrić, kasniji tajnik splitske Pedagoške akademije, u knjizi Nenada Lovrića Splitski razgovori prisjeća se odnosa društvenih slojeva u Lučcu:

Između težaka i zanačija postojao je stanoviti antagonizam. Težaci su obožavali svoja polja i visoko cijenili mukotrpan rad oko vinove loze te su zato zanačije gledali ispod oka, najviše zato što ovi nisu imali potpuno siguran izvor zarade. (...) Dok u starija, austro-ugarska vremena, splitski težak ne bi lako dao kćer za zanatliju, osim ako ovaj nije bio obrtnik (...), niti za ribara, a često ni za radnika, dotle već tridesetih godina 20. stoljeća dolazi do obratne situacije. Težačke kćeri slabije kotiraju kod udaje, dok se kćeri zanatlija i radnika ne denjaju težaka. ${ }^{21}$

Ova zapažanja ogoljuju dosada u hrvatskoj historiografiji nedovoljno percipiran i zasigurno neobrađen fenomen „aristokracije radništva“, posebnog sloja radnih ljudi koji zbog stečenih, darovanih ili posve zamišljenih povlastica sebe smatraju povlaštenim slojem unutar vlastite zajednice. Tako splitski težaci zbog svoje privrženosti radu ne žele među svoje potomstvo pripustiti utjecaje drugih slojeva. Eric Hobsbawm primijetio je postojanje izdvojenog sloja više radničke - niže srednje klase - koja po percepciji svoje vrijednosti teži izuzimanju iz svog miljea definiranog običajima i društveno-političkim odrednicama. Hobsbawm zaključuje da razvoj klase „bijelih ovratnika“,22 stručnjaka sa završenim visokim školama, posebnim menadžerskim i tehničkim znanjima, od kraja devetnaestog stoljeća

\footnotetext{
Isto.

18 A. Kudrjavcev, Upotrazi za izgubljenim Mediteranom, 59.

19 B. Radica, Novi Split, 231.

20 Podaci prema: B. RadicA, Novi Split, 230.

21 Nenad Lovrić, Splitski razgovori, Zagreb - Split 2014., 52-53.

22 White collar, eng. - nasuprot "plavim ovratnicima“.
} 
istiskuje ovu aristokraciju radništva. ${ }^{23}$ Bez prevelike želje da u svojoj liniji argumentacije ovisimo isključivo o sjećanju Prvislava Petrića, njegov slijed prisjećanja postavlja slično pitanje - je li osjećaj vlastite vrijednosti kod težaka uvjetovan težačkim mentalitetom ili ekonomskim realnostima? Je li do promjene u ženidbenim navikama došlo zbog krize koja dolazi sredinom dvadesetih? Ili ranije. ${ }^{24} \mathrm{Na}$ koje je sve načine kriza mogla utjecati na težački mentalitet? Dalje, kad se taj mentalitet obilježen visokom razinom samopoštovanja uopće formirao? Treba li argumente slijediti prema vremenu velike konjunkture $s$ kraja devetnaestog i početka dvadesetog stoljeća ili čak u ranija vremena? U ovom trenutku i na ovom mjestu možemo samo konstatirati da prevelik broj pitanja ostavljamo za drugu priliku.

Obraćamo se i Miljenku Smoji - jednom od najpoznatijih splitskih kroničara - koji je u svoju pisanu ostavštinu unio neke od najzapaženijih stranica koje pred čitateljima rastvaraju splitski mentalitet. Smoje, dijete Velog Varoša, više od kvalitetnog autora bio je i prvorazredan istraživač ljudskih sudbina, želja i mentaliteta. Najvažniji nam je u ovom slučaju upravo kao kroničar mediteranskih mentalnih obrazaca. U idućim rečenicama svog Velog mista opisuje odnose dva suprotstavljena društvena sloja:

Težaci i ribari, te dvi najbrojnije skupine splitskoga građanstva, nisu se ni marili susrest. Ribar, beštimadur i proleter, (...) nikako nije moga trpit težaka. Jema poja, vinograde, kuću, koćetu, konobu punu vina, i po dva i po tri prajca (...) a u konobu s judima nikad nije seja i popija vrč vina. ${ }^{25}$

Nakon što je dalje opisao verbalna nadmetanja u kojima se izmjenjuju najgore pogrde $s$ obje strane, Smoji se nameće zaključak:

A gledajući samu sliku, tu finu harmoničnu kompoziciju - ribari u vitkin leutima, veselu šarenu povorku sivac naprćeni lozjen, mišinan, maškliniman, motikan i u sedlo uvajenin težacima, $s$ ispruženin nogan da jin opanci ne stružu tle - čovik bi promislija: idila! Idila skladnoga gradića. ${ }^{26}$

Ipak, ideja javnog sukoba - nadjačavanja u verbalnim povredama - kao konstanta prožima mediteranske gradove i duboko je ukorijenjena u literaturi, beletristici, publicistici, koja je u prvom redu informirana iskustvom stečenim u dugom trajanju. Javni sukob i ruganje kao njegov neodvojiv dio i jedan od načina urbanog života preživjelo je desetljeća u kolektivnoj memoriji svjedoka vremena. Uz ruganje usko je vezana šala koja nema ni malo „obzira ni milost[i] naspram slabijima, glupljima i nakaznijima [čime se nastojalo] samodokazivati vlastitu moć i vrijednost“. ${ }^{27}$ Vladimir Rismondo se u knjizi Splitski razgovori prisjetio podcjenjivačkog odnosa manjeg broja građana prema težacima. Prema njegovom sjećanju, pri prolasku težaka preko Rive, govorilo se: „Riva je puna mandrije. ${ }^{“ 28}$ Asja Kisić

23 Eric Hовsваwм, Worlds of Labour, London 1984., 251.

24 Branislav Radica tvrdio je 1931. godine da je zbog Prvog svjetskog rata došlo do pauperizacije težaka te da su odlučili napustiti polja i okrenuti se manualnom radu u gradu kao lučki i tvornički radnici. Nav. prema: B. Radica, Novi Split, 238. Njegovi navodi ne predstavljaju definitivan odgovor, ali nude trasu kojom se budući istraživači mogu kretati.

25 Miljenko Smoje, Velo misto. Prvi dil, Split 2004., 15-16.

26 Isto, 16.

27 A. Kudrjacev, Upotrazi za izgubljenim Mediteranom, 93. 
također je referirala na splitsku okrutnost i uživanje pojedinaca u „krvavim vicevima“.29 Zaista, nudi nam se i zaključak - formiran nakon uvida u dio splitske humorističke periodike $^{30}$ - da je odnos prema slabijima bio okrutan i poput jedne velike „insajderske“ šale, neprozirne percepciji stranaca.

Postoje, međutim, javni prostori koji ne trpe previše sukoba. Prostori uljuđenih trgova u kojima ponašanje najvećim dijelom potpada pod specifične ceremonijale koji su se formirali u dugom trajanju prethodnih godina i desetljeća. ${ }^{31}$ Jednu od splitskih pjaca koja je zamišljana kao mjesto oslobođeno sukoba i grubih riječi Kudrjavcev opisuje kao:

[Trg] koji se davno zvao Piazza dei Signori, dakle Gospodarski trg, [koji je] posjedovao izrazito sociološko značenje. Na njemu nije bilo mjesta za prosti puk. Bio je to prostor za isticanje vrijednosti koje su se sastojale od staleških prednosti, zatim od ponašanja, odijevanja i pojavljivanja kao osobnosti društvenog statusa i naročite funkcije. ${ }^{32}$

Teatralnost i visoka razina uvježbanosti takvog života nije izbjegla onima koji su analizirali splitsku međuratnu javnu scenu. Trenuci urbanog smiraja pružaju mogućnost promatraču ili memoaristu da misao o gradu kao teatru unese u svoj narativ. Miljenko Smoje tako $s$ jedne strane piše:

Evo i sad, u ovu večernju uru kad nima ni sprovoda, ni procesjuna, ni demonštracjuni, na velikoj, uvik otvorenoj gradskoj pozornici ijade građani igra svoju precizno razrađenu ulogu. Činovnici, obrtnici i ništo študentarije sidu prid kafanskin štekatima na Rivu,... ${ }^{33}$

Anatolij Kudrjavcev s druge strane analizira ponašanje gradske elite na sličnu temu:

Oni najprivilegiraniji, što su sjedili u kavani, dobivali su hitna izvješća o svim događajima, a možda su čak upravo oni bili začetnicima predstava, kao scenaristi, kao dramaturzi i kao redatelji. ${ }^{34}$

Unatoč definiranosti i uvježbanoj uređenosti života elite, svakodnevica već spomenutih ribara-proletera, težaka i ostalih manje imućnih pripadnika splitskog društva, u međuratnom je razdoblju radikalno izmijenjena političkim raslojavanjima. Miljenko Smoje je u Velom mistu kazao: „Sve manje Splićani gre u procesjune, a sve više u demonštracjune.“35 Početnih nekoliko poslijeratnih godina provedeno je u rastrganosti politički mislećeg dijela stanovništva između straha i nade, straha od talijanskih teritorijalnih posezanja i nade za spasom koji je trebao doći iz Beograda. Generalno, to je bilo vrijeme optimističnog postujediniteljskog političkog braka Dalmacije i Beograda. Split kao najveći grad Kraljevine na Jadranu zamišljen je u ulozi kulturnog i gospodarskog centra, ali taj se projekt središnje

\footnotetext{
N. LovRIĆ, Splitski razgovori, 11.

Isto, $40-41$.

Riječ je o brojevima lista Štandarac, koji je izlazio do 1935. do 1944. godine.

31 „Ta večernja pjaca bila je strogo podijeljena na zone nepisanim propisom što ga se desetljećima nije kršilo.", cit. prema: Duško KečKemet, Split moje mladosti, Zagreb 2008., 50.

32 A. Kudrjavcev, U potrazi za izgubljenim Mediteranom, 153.

33 M. Smoje, Velo misto. Prvi dil, 17.

34 A. Kudrjavcev, U potrazi za izgubljenim Mediteranom, 155.

35 M. Smoje, Velo misto. Prvi dil, 13.
} 


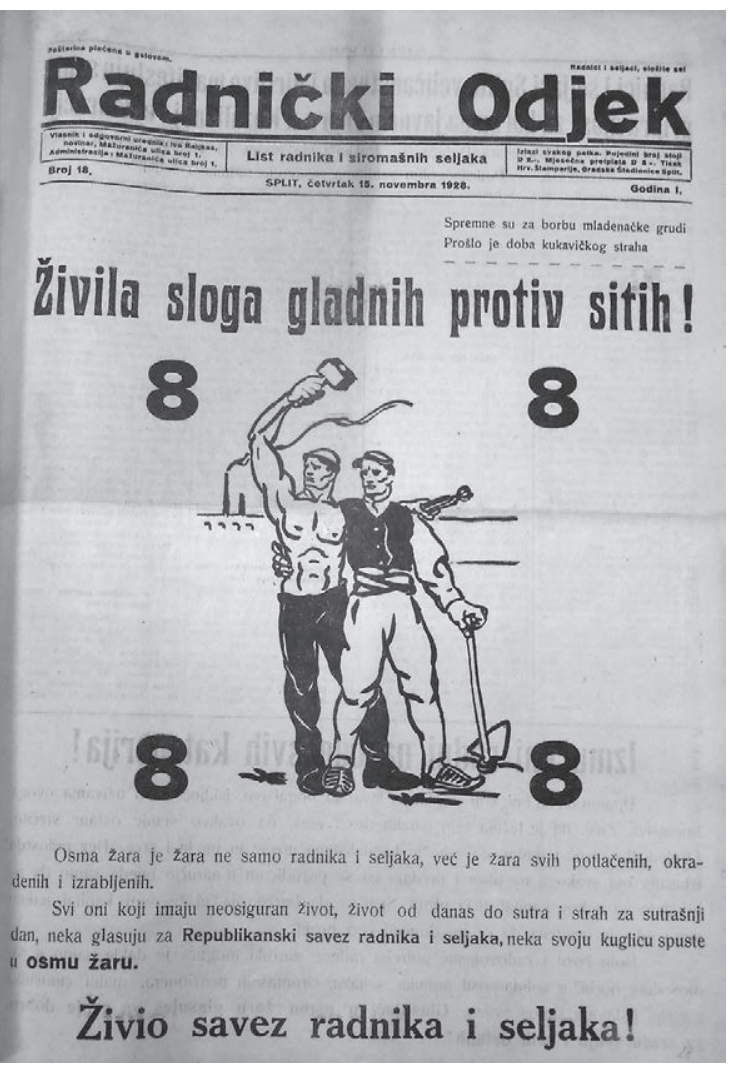

Sl. 1. Ressentiment u slici i riječi: naslovnica Radničkog odjeka pred lokalne izbore 1928. godine

države provodio uz razne zastoje i nesnalaženja inherentna djelovanju državnog centra na periferiji. Ovaj gospodarski i kulturni projekt imao je jedan krajnje radikalan element unutar svoje ideološke podloge - Organizaciju jugoslavenskih nacionalista (Orjuna), političku skupinu usmjerenu na brahijalno suprotstavljanje svim snagama koje se na ovaj ili onaj način nisu slagale s politikom unitarizma. Orjunu ipak karakterizira nekoherentna ideologija i naglasak na organizacijski oportunizam pa su tako njezini odredi u razdoblju od 1923. do 1924. razbijali štrajkove radnika koje je organizirala zabranjena Komunistička partija - ne bez organiziranog otpora komunista. Istovremeno su pak bili spremni „poduprijeti štrajkove u tvornicama u stranom vlasništvu, osobito talijanskom“.36 Paralelno s vrhuncem utjecaja Orjune, u Dalmaciju i njezin centar Split počeli su pristizati politički konkurenti raznih boja. Pojava Hrvatske seljačke stranke pod vodstvom Stjepana Radića zanosila je sve veći broj građana, osiguravajući nakon 1925. velike brojeve pristaša. ${ }^{37}$ Godine 1926. održani su izbori za splitsko općinsko vijeće na kojima je pobijedila lista Saveza radnika i seljaka, čiji su kandidati bili pripadnici ilegalne Komunističke partije Jugoslavije, a u gradu Splitu to su u najvećem broju bili težaci i zanatlije. No, njihovi mandati izboreni na biračkim mjestima poništeni su administrativnim putem. Godine 1928., na novim izborima za lokalnu vlast, Republikanski savez radnika i seljaka ponovio je svoj uspjeh, iako manji nego prije dvije godine. Niz povjesničara, od Drage Gizdića do Zdravke Jelaske Marijan, ponudio je objašnjenje da je vrlo visoka zastupljenost težaka na listi jedne radničke stranke posljedica paradoksalne ukorijenjenosti ideja socijalizma i ljevice u težačkim redovima. ${ }^{38}$

Vratit ćemo se ovim povodom u okružje Varoš, koje tridesetih godina dobiva nadimak „Mala Moskva“. Neobična je disproporcija brojeva poznatih komunističkih aktivista i simpatizera koji su potekli iz ovog područja nasuprot ostalim dijelovima Splita, a ovaj rasad-

\footnotetext{
36 Stevo ĐurAšKović, „Ideologija Organizacije jugoslovenskih nacionalista (Orjuna)“, Časopis za suvremenu povijest, 43/2011., br. 1, 241-242.

37 Tonći ŠItin, „Stjepan Radić i Dalmacija (1918.-1928.)“, Radovi Zavoda povijesnih znanosti HAZU u Zadru, 42/2000., 452.

38 Marijan Buljan, „Splitski općinski izbori 1928. godine“, Historijski zbornik, 66/2013., br. 3, 357.
} 
nik političkih talenata i antifašističkih boraca tridesetih je godina bio mjesto u kojem su se mnogi aktivisti skrivali i održavali tajne sastanke. Politički aktivizam ljevice nije podrazumijevao samo sudjelovanje na sastancima, već se od borbenih aktivista također očekivalo djelovanje u sindikalnom i općem radničkom pokretu. List Radnik iz 1935. godine tako se na svojim stranicama bavio širenjem lijevo angažiranih vijesti, pritom potičući ressentiment potrebitih prema bogatima, primjerice sljedećom porukom: „Kad bi bila poskupila luksuzna roba, slegli bismo samo ramenima, jer luksuznu robu troše oni kojima i veće poskupljenje te robe neće baš mnogo olakšati džepove. “39

Ako je Eric Hobsbawm bio u pravu kad je istaknuo ulogu nogometa u Velikoj Britaniji kao jednog od fenomena modernizacije, posebno kroz profesionalizaciju igre, ${ }^{40}$ ne bismo bili daleko od sličnog zaključka u slučaju Splita, samo što bismo dodali važnu notu političkog aktivizma koja prožima pojedina sportska društva u gradu. Sama nogometna igra u Split ulazi kao iz legende, preko osnivanja jezgre nogometnog kluba u praškoj pivnici. U vrlo kratkom vremenu ona više nije bila dokoličarska povlastica uske manjine studenata i rapidno se širila u raznim urbanim krugovima poprimajući masovnu popularnost. Pripadnici urbane mladeži - dio buržoaske izgubljene generacije o kojoj u historiografiji ne znamo dovoljno, a koja je spremno prihvatila ranije obrazložene obrasce ruganja i koji su bili - prema Vladimiru Rismondu - „nositelji mentaliteta nerada“, „satima i satima [su] znali debatirati o nogometu (...), kao da se u gradu osim baluna ništa drugo i ne događa“. ${ }^{41}$

Profesionalni obrasci djelovanja prihvaćeni su u neposrednom poslijeratnom razdoblju, uz proliferaciju većeg broja klubova i sportskih društava. Nogometni klub Hajduk imao je povlaštenu ulogu u sportskom životu Splita i u procesu profesionalizacije koji je potakao rudimentarnu medijsku industriju. Neki takvi mediji, poput časopisa kratkog vijeka Football: list za propagandu sporta u Splitu iz 1929. godine, bili su u potpunosti posvećeni minucioznom praćenju Hajdukovih utakmica. ${ }^{42}$ Paralelno s procesom „zaljubljivanja“ širokih masa u klub „bijelih“, širilo se djelovanje splitske političke ljevice u sportskim društvima. Od njih je svakako najvažniji varoški nogometni klub Anark (Anarh, kasnije poznat i kao „Crveni“ Split), koji je u ovom međuratnom razdoblju prolazio kroz više zabrana djelovanja i preimenovanja. O fenomenu „Crvenog“ Splita pisao je Vicko Krstulović, ističući da je „aktivan proces razvijanja klasnih snaga radničkog pokreta u Splitu i Dalmaciji, stvarao (...) uslove u kojima se pristupilo osnivanju prvih radničkih društava, nogometnog kluba 'Anark', pjevačkog društva 'Jedinstvo'“ ${ }^{43}$

$S$ druge strane, negativna strana profesionalizacije modernog sporta nije izmicala iz vidokruga pojedinih Splićana. Vraćamo se na list Radnik, u kojem anonimni autor članka 1935. godine piše: „Radnička omladina vidi svog neprijatelja u trgovačkom sportu. Ona je svijesna svog zadatka, ona ustaje protiv trgovine u sportu podižući svoj radnički, masovni

39 „Zašto je kruh poskupio?“, Radnik: sindikalno glasilo radničke klase za Dalmaciju, br. 4, 12. 10. 1935., 2.

40 Eric Hовsваw, , „Mass-Producing Traditions: Europe, 1870-1914“, The Invention of Tradition (ur. Eric Hobsbawm i Terence Ranger), London 2012., 288-289.

41 N. Lovrić, Splitski razgovori, 20.

42 Primjerice članci: „Nastavak prvenstvenog plesa“, Football: list za propagandu sporta u Splitu, br. 4, 14. 7. 1929., 1; „Hajduk vodi!“, Football: list za propagandu sporta u Splitu, br. 5, 29. 7. 1929., 1-2.

43 Mario Garber (ur.), Crveni „Split“", Split 1984., 9. 


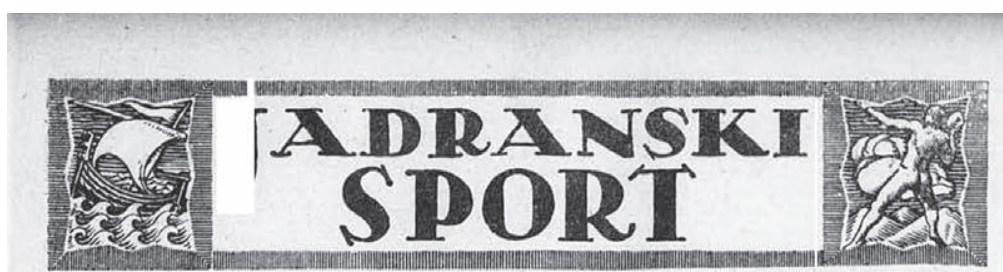

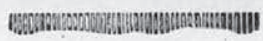

IZLAZI U SRIJEDU

VEČER KAO PRI-

LOG DNEVNIKA

" NOVO DOB A

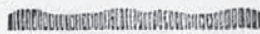

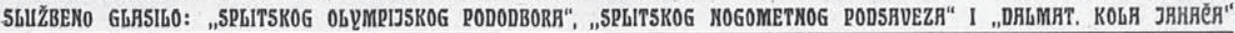

\begin{tabular}{|l|r|r|r|r|}
\hline Br. 11. & $\begin{array}{r}\text { UREDNISTVO: NARODNI TRG Br. 10. } \\
\text { I POST. PRETINAC 38. } \\
\text { UPRAVA: TRUMBICEVA OBALA Br. 1. }\end{array}$ & S p li t, 8. lipnja 1921. & $\begin{array}{r}\text { Odgovorni urednik: BOGUMIR DOLEŻAL. } \\
\text { PRETPLATA: Mjesetno Krana 12- } \\
\text { POJEDINI BROJ Kruna 4- }\end{array}$ & God. II. \\
\hline
\end{tabular}

Pravila Foot-Ball igre. bio, bile bi vrlo rijette utakm'ce proti lspat-

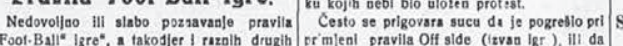

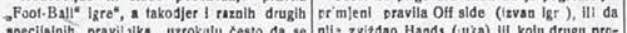
specijainith pravil lika, uzrokuju cesto da se alj: zvitdao Hads (uiza) ill koju drugu propil utakmicama cuju razoi poklici I mran stcaje publike, kole fe u a jrecem djelu neosno vano. Porici kofl se coju, smetaju suca I
igrace, I obicao davaju poroda ispadim a kojl lporta semo btetulu.

Da se doskocl neopucenostl jedaoz dijela jobltel,a tog sporta, to da lati upozadu asjva zaljo propise igre, donasati cemo iste u ai. zu Clanaka, uvj real, da cemo time pratit posjetlocima igra smjeralcu, po ko.oj mora presudjivatl odredbe suca I soma igra.

Obradjene izvatke iz pravila igre donasat cems po eogleskom Referees Chart", koj! jo mjerodavan an svo Igro clavora F. I. F. A. (Feveratlon lateraatlonal de Foot Ball As. socilatios, dakle I za

Nogometnog Saveza.

F.i. A. Jo syjetska orgaolzacija, ko I. sudac.

Potetl cemo , tim pogiavijear stoga, da se aportusi asjptije upute u teska zadaca acsportasi anjpri|

Negometai suei so zttve viastite IJubavi za oport. Polozaj im je vtlo delikatso i puo odgo voracsti. Oa je domious litis a igrl, kolli de
fialitivno i bez opoziva upravlja Igrom. Da liallivno i bez opoziva upravlja Igrom. Da oa uzmogoe zadovoljiti postavljens] mu zadaci, opskrbljuju

o vlast ms.
Po duhu I smislu pravilaika sud ic je jed

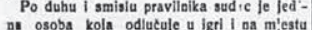
ni osoba koja odlucuje u igri I na m',estu
tilesava sporove, pa se attko ac amiljo uaztilesava sporove, pa se altiko ae amilio
bati u Izrleinje fe njegove presude.

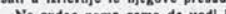

No sudac nema samo da vodi igru. Po sa. vezolm pravilims, I onima F. I. F. A, oo fe zvao, da ureduje za slucaj petrebe 1 medju hilabuceolem a sudac andjo da so time mote urrokovazi nered ma igrallstu; vrijedja il tho suea zbog ojegovih presuda, ili vrijedja igrate a igri; ill usrokuje koli mu drago nered na igrallistu, audac fo, viastan prekloutl red in igralistu, eudac fe, vlastan prekloutl smetajo, blli to pojedlocl ill cllela jedaa gra pa Ijudi.

Pa judi. Igre zabraojuju surovu Igrv, poglbeljau Igra I nesportako aepristojao ponalioje Igracka aa Igrallstu. Sudac mote, u nekim slucalevima dapate mora lakijucitl igraca iz igre, ako se grijesi o tikove proplse. Priljo vego sto audac upotrebl ovako stroge mjere, or co uvijek opomeatitl doticalka, a kod opetovaoja lokijucl co ga. U osoblto teskim alucalovima moze ofstrabitt igraca I bez opo meat. Jedac of tat

vrijedjanje suca. dar I ovi mu se moroju pokoravatl I ooda ako je on ladao krivu preaudu. All dok proplsi Igro I savezoi pravilalel daju sueu tuko ve I tollke atograalceae ovlasti, stavljaju ga
intl proplal pod koutrolu I discipllanrau vlast intl propla pod koutrolu I disciplianarnu viast pjezovih kolega. Svi sucl akupa saclojavaju -Kolegil sudaca". Tol Jo rolegil zvan da lo biljeaju sudacke ovlasti ldu pred tol forum. Sniki sudic prile aego dobljs ovlant audjeSraki evdic prijo aego dobljs ovlant sudje-
uja a Igri. mora so podvrgoutl laplttma. I Iopl-

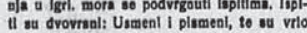
strogi. Tu strogost uvjetuje suma delikatoont polozeja suceve. U suca moraju svi Imati povjereaje, a da mogu Imatt to povjerepje, mo I mora ith sastl od mah apllieintl.

U priacipu viljedl pravilo, da protl odred bama suca nema calbo. Toj lo priacip pot. puno opravdas, lor kad toga prlacipa

Za A.C Sparta: Peyr, Hojer-Posplail, KoJands - na 5 koraks pred brankom -
prihvat loptu, streljs - all preko preske! pro- Trećs utakmiea, koju je Stavia odigrala

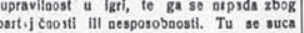
uepravaedao okriviluje. Nema suca aa svi|et', koji bi mozao sve da vidi. Ali imade u slabili. Neki vide vise, drugi manje. To jo posijedica moog'h mamenata koji uplivaju on sucu tekom igre. Brzina aplikacile, dobar pogled aad igrom, tJelesna sposobaost izdr2ati maogo vecl aspor od Igraca, dusevao raspolotenje suci, kole se ae dade navilat-
kao ast, sve to upllva na prigodou sposobi kao sat, sve to upliva an prigodou aposobi
post guda. Sre se te maue moreju socu cost suda. Sre se te maue moreju soce
o rostiti, jer le ovjek pretpostavkg, da on ra o rostiti, jer le uvjek pretpostavks, da on ra

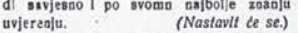
Nogomet « Cehoslonačkoj. PRAHA, 29. v.
P S. K. Slavla-A. C. Sparia 1:0 (0:0). Da. naśaja jo igra po redu 25 . izmedju gornjith
klubova, koji so takme o prvenstvo jos od g. 1896. Napetost, kojom ocekivasmo ovaj matsch, billa je neobiéaa. Ns Igralistu A. C. Sparte sjatllo se preko 20.000 gledalaca. Mimo ost slith bili su prisutni: Ministar Nar. zastupnik Stribeny, Dr. Dubek za Gradsko Vijece, tri franc. atteta gg. Delsvarque, Peteraon I Janois kao néesnicl Mas

gara itd, Taćao u 5.h nastupilie:
Za S K Slavia: Berànek NyU-Raca, LoosFichta-Cipera, Lutovaky-Novak-Vanik Blahoik-Subrt. lenaty - Kada-Perner, Rektorys - SediacekFiàt-Janda-Mazal, sudac g. Kraus. Nastap obaju teams bio je odulevljeno pozdravijen od publike. Igra je posela zivim tempom. Navala je Sparte sillija od one
Slavilje, koja je nastupila as dvije zamjene a obim opojkama, ps stoga Sparta izvodi vile,

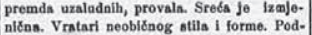
nif́na. Vratari neobißnog atila i forme. Pod-
vige su Siavie, rjedje all promilljene, tako vige su Siavie, rjedje all promilljene, tako
da th Sparta jedva izdrit. Janda je neobieno i neoprostivo nespretan pred brankom. Sparts uopée igra mnogo bolje u polju nego ll pred
brankom. Vanik Je dula navale, bistro I brankom. Vanik Jo duba navale, bistro I
oknto prenosi Igru sad na jedno, sad na oknto prenogi Igru sad na Jedno, sad na
drago krilo. Cipera je najbolji igrad dana. Polavrijeme 0.0. - Nakon predstavke igra
se razrijs a neobienaim elasom. U 2. \&. prose razpijs a neoblénim elazom. U 2. C. pro-
dire Subrt, a zgodaa čas ce 1truje long passlog, Novak stopuje, pa premda opkoljen
od oba backa, dava po remili shoot I billežl od oba backa, dava po remijl shoot I billežl
prvi goal. Uraebeanl pljeask. Igra se nastavprvi goal. Uraebeanl plJesak. Igra se aastav-
$1 \mathrm{ja}$, kao od potetka: veoma visokog alvesus, sa ojajnlam momentims 1 irmjeniơnim sanss. ma oboatrano. Ali u gL. . nasta sbrka. Rektorya jo u offolddu, hvata dodanu lopta, uzdaíni
sudac g. Singor (AC Sparta) mašo sa zastasudac g. Singor (AC Sparta) maš as zasta-
veom, S Stavis dife ruke, a aodac se okamenio. Rektorys centruje u kazneai prostor, na ort Jo RAces, lopts ga navodno dotakne u
nadlaktleu - ito on aporno poribe - a nadiaktleu - ito on aporno poribo
sudac opet no vidi, lopta jo u igri. 0 to

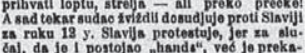

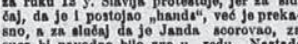
suea bl navodao bilo sve u redu.
propirka. Slavia napubta igrallitsto. Tako Jo ovaj anjinteresantalil, inade prijateljokl, matech ove sezone svrdio neregularno, kako trrdo Sisvisti, radi komprom B. M. V skostl pojmova o prof Igraja finalo 12.6. a Däaseldorfo.
Foot-ball,

otisl su $12 \mathrm{sa}$ rajeva lakoatletičari dr. Teodor Lukad I Po. Jiga, a iz Sviearske polaxi tamo dr. Zdravko Jetsnovic, takodjer iz Sarajeva. De. Lukn vir. Jeftanovid vrio su dobro poznati ka pleso je u Śricarakej anoj. Dr. Lakać na par knjigs o lakoj atletlei fo par knjiga o lakof atletlei I o sporta uop6e, a dr. Jeltanovlé je nedavno postigao bvicarsekunda, dok je svjetski rekord blo 10 se sekunda, dok je svjetski rekord bio 10 se kandi sokuda. Poluga je posant kao
lako atletléar a Svedekoj. Sva trojlea su Elanovi Sporskog kluba "Slavija".

Imena nasih lakoatlota obećavaju nam, da te se nab lakoatletski bort po prvi put i stranom svijetu afirmiratl. Eventualne uspje he javit temo.

Londonski meeting. Driave pobjedalce priredile su u Londona, a organizaelja prepust le EagleskoJ, vellika lakoatletska natjecanja. Pozvane su bile samo Engleska, Belgija, Francuska I ltalija. Ta su natjecanja
s'tula malim Olympijokim Igrama, te su po sidila malim Olympijskim Igrama, te su po. Natjecanja su bila provedens as ijegom igrallstu Stamford Bridge. Evo najvaźnijil rezultata:

$100 \mathrm{~m}$. Brochart (Belg.) o 11" 4
$200 \mathrm{~m}$. Brochart (Belg.) a $22^{2 \prime}+2$ $200 \mathrm{~m}$. Brochart (Belg.) an $22 "$ $400 \mathrm{~m}$. Mawby (EngL) u $5 \mathrm{~T}^{\mathrm{N}}$

Utakmice raprezentacija.

Engleska-Belgija 2:0, U engleskol mom eadi 6 profesionala. To je posljedica razro-

Itallja.Belglia 3:2, Itallja.IIolandtia 2.2 Prvaei u nogometu.

Maroko, LOlympique tude u finalu Racing Club 4:1.

Spanjolska. Atletio F. C. Blibao tuce uf fi. Slu Atletlo Clob Madrid 4:1.

Holandlija. Ove godine odnijela je prventvo Jedna provinejalalas moméad. Lanjaki prvak AJaX.Amaterdam bio je potacén Vanjski foot-ball.

Ceska. Prvenstveas Slavin-Sparta 1:0, polavreme 0.0. Igra prekinuts a drugom pola. Brao: D, F. C. Prag-Moravska Slavin 2:1; iktoria Ż.Makabi 1:

Pardabicet Pardublec-Vrlovice Praha 2:1. Austrija. Rapid-Vlenus 3:2; Wacker Sportdol thugel 3:2; Fac-Admirs 3:2; Wal-Hertha $2: 2$.

Ugaraka. Fte.-K. A. C. 1:1; M. A. C.U T.E2; vII. Kotar B. T. C. 3:1; T. T. C. $33^{4} \mathrm{~F}$. 0:0; Vasas-III. Kotar 1:0.

Njemacka. Semifinale zs prvenatvo Nje

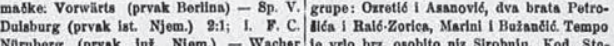
Hello - Wacher Je vrlo brz, osoblto niz Sirobuja. Kod Sto-

Laka Atletika.

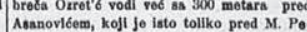
trosibem. Istlm redom prolazo vozaci pri zsokreta u Krilo, samo uz véo raxmake. Kod zsokrota nhvatl E, Petrollida gro u nogu, Polazak nasih lakoatleticara na, Masary- to jo izgabio trl minuto.

kove igre" a Prag. Ovilh dansi pollo Jo u Do Krila $(15 \mathrm{~km}$.) voxio jo Ozretic 26 , Prag nekolliko nasilh lakontleticara, da za- Aosnovil6 $2725^{\circ}$, M. Potrolli6 2720". otupaju Jugosiavija pri velebnim natjeea- Pri povratku profllo fo prugom nekoliko njlma, koju spremaju Ceal a podant ovomu automobila, koji su utvituall prablau, sto je prvom preajedniku. Na "Mabarykove Igre" pozvase au avo nacije, to je I odaziv vrio poluzena vremena blla manogo bolya da toga I Belgijanaca.

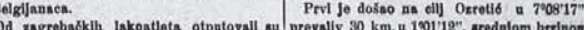
Sendic, Sekullt, Buljik, Kirln, Oadpar, Zlot, od $29 \mathrm{~km}$. 508 metara' na sat, burno akts.

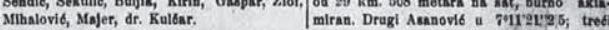


sport, kojim će nadoknađivati sve ono što izgubi u učionama i u radionama. “44 Sama nogometna kultura u široj javnosti i među navijačima nije bila na zavidnoj razini. Tako je puno desetljeće nakon dolaska nogometa u Split, 1921. godine, list Jadranski sport smatrao potrebnim u nekoliko nastavaka objaviti nogometna pravila. Uvodni članak ove serije korio je nerazumijevanje sudionika masovnog spektakla na tribinama: „,...) nedovoljno ili slabo poznavanje pravila 'Foot-Ball igre', (...) uzrokuju često da se pri utakmicama čuju razni poklici i mrmošenje publike, koje je u najvećem dijelu neosnovano. Povici koji se čuju (...) obično davaju povoda ispadima koji športu samo štetuju. ${ }^{\text {"45 }}$ Zanimljivo bi bilo postaviti pitanje koliki je u tim ranim godinama razvoja nogometa bio odnos zadovoljstva u promatranju igre i zadovoljstva u osjećaju pripadnosti jednom kolektivu i iskustvu mase.

Na stranicama spomenutog lista Radnik krajem tridesetih bilo je prisutno naličje sve boljeg poslovanja splitske cementne industrije. Ovdje ćemo se prisjetiti rada dr. Uroša Desnice, koji je tih tridesetih bio član i potpredsjednik Upravnog vijeća poduzeća „Split“, anonimnog društva za proizvodnju cementa portland. ${ }^{46}$ Upravno vijeće ovog poduzeća mali je who is who viših slojeva splitskog društva. U njegovom su radu između ostalih sudjelovali dr. Prvislav Grisogono, bivši ministar u vladi i veleposlanik; dr. Josip Smodlaka, koji je u drugoj polovici tridesetih bio odvjetnik u Splitu; dok je pravni zastupnik poduzeća bio dr. Ivo Tartaglia, bivši gradonačelnik i ban. Bilo bi vrlo zanimljivo prema dostupnim arhivskim ili drugim vrelima rekonstruirati cijelu društvenu mrežu koju su ovi i slični pojedinci formirali tridesetih godina, naravno, i u prethodnom desetljeću. Relativno je lako doći do podataka o važnim pojedincima, društvenim prvacima pojedinih gradova. Već je velik i iznimno vrijedan posao u istraživanju ekonomske nadgradnje učinila Zdravka Jelaska Ma-

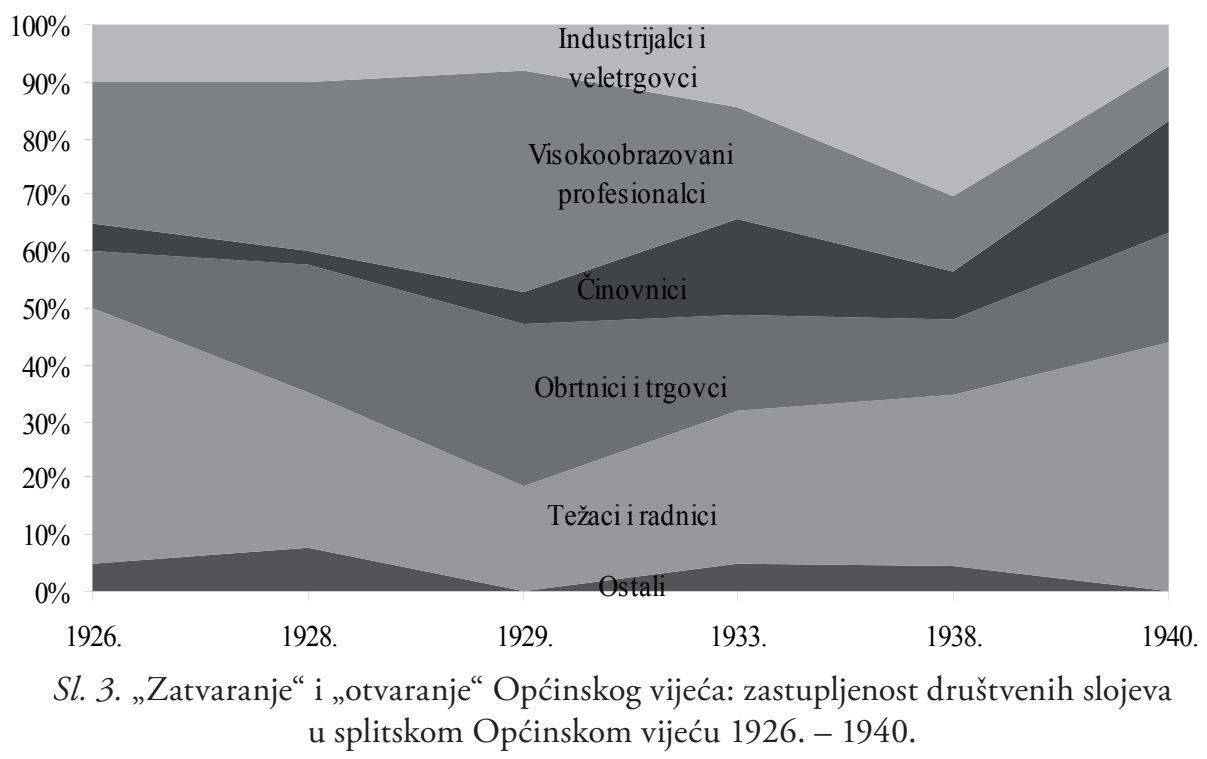

\footnotetext{
44 „Šport nekad i sad“, Radnik: sindikalno glasilo radničke klase za Dalmaciju, br. 1, 21. 9. 1935., 4.

45 „Pravila Foot-Ball igre“, Jadranski sport, br. 11, 8. 6. 1921., 1.

46 Hrvatski državni arhiv, Zagreb, fond 163, Banovina Hrvatska, Odjel za obrt, industriju i trgovinu, „Godišnji izvještaj i zaključni račun 'Split-a' za godinu 1937.“, kut. 83.
} 
rijan u knjizi Grad i ljudi. Bilo bi korisno shvatiti kako je izgledala ona struktura koja je činila temelj uspjeha pojedinaca u toj nadgradnji, kako su izgledale političke ili gospodarske veze koje su ih umrežavale i održavale u takvoj, brojčano maloj, klasnoj zajednici. Koliko bismo vrijednoga mogli spoznati iz dosad nenapisane prozopografije splitske elite? Pritom, dakako, ne mislimo samo na, primjerice, članove upravnih odbora. Važno je u svako istraživanje te vrste uključiti kulturnu i intelektualnu elitu.

U iščekivanju takvog pothvata, ovdje nudimo mogućnost promatranja međuratnih socijalnih trendova kroz grafički pregled političkog fenomena u urbanoj političkoj eliti kojeg smo nazvali „zatvaranje“ i „otvaranje“ Općinskog vijeća u razdoblju od prvih izbora 1926. do vijeća imenovanog ukazom 1940 . godine. ${ }^{47} \mathrm{U}$ prikazu dajemo pet velikih, široko definiranih društvenih slojeva - industrijalce i veletrgovce, visokoobrazovane profesionalce (odvjetnici, liječnici, arhitekti,...), privatne i državne činovnike, obrtnike i trgovce, a težake i radnike promatramo u jedinstvenoj cjelini. „Zatvaranje“ Općinskog vijeća podrazumijeva njegovu početnu otvorenost - pod tim shvaćamo mogućnost ulaska i izbor većeg broja težaka i radnika u sazivu iz 1926. godine, u prvim lokalnim izborima poslijeratne masovne demokracije. „Zatvaranje“ polazi s 1928. godinom, a vrhunac doseže prvim imenovanim vijećem 1929. godine. Sva su ostala vijeća nakon toga imenovana, čime njihovi sastavi više postaju autolegitimacijski projekti centralne ili zagrebačke vlasti - ali i u tom obliku upućuju na bitne strateške ciljeve raznih svjetonazorskih optika tih vlasti. Jednostavno možemo pratiti na koji društveni sloj se u zadanom trenutku režimi mogu i žele osloniti.

Na kraju možemo rezimirati jednom porukom o pročitanoj literaturi koja govori o specifičnostima mediteranskog, dalmatinskog i splitskog života. Pitamo se, je li potrebno ovdje opisane splitske društvene slojeve spasiti od - kako je Edward Thompson rekao - „strahote povijesnog zaborava“" 48 Dojma smo da je Split uz Dubrovnik onaj hrvatski grad koji ima najveći (u nedostatku boljeg termina) rezervoar kolektivnog sjećanja iz kojeg se u literaturi povlače predodžbe o mentalitetu stanovništva. Grad Split, kao i njegovi ljudi, imaju najveći potencijal svog kolektivnog sjećanja, koje slijedi jednu dugu tradiciju i ne prekida se lako na prijelomnicama političke događajnice. Riječ je o perspektivi dugog trajanja. Čitanje mnogostrukih splitskih političkih, kulturnih, intelektualnih, sportskih, elitnih i pučkih tradicija, koje i danas pobuđuju strasti, čini da nam se svaki pojedinačni „Split“ uvijek čini kao da je - slično naslovu knjige Duška Kečkemeta - Jučerašnji Split. Potreban je samo jedan pogled niz mnoštvo ovdje naznačenih tradicija i on oživljava, postaje razumljiv i dohvatljiv.

$\overline{47}$ Prikaz sastavljen prema podacima u: Z. Jelaska Marijan, Grad i ljudi, 118-142.

48 E. P. Thompson, The Making of the English Working Class, London 1992., 12. 


\section{$\cos$}

\section{Social Structures in Interwar Split: A History FROM THE BOTTOM UP}

This paper analyzes certain topics from the history of Split's social structures between the two world wars. The perspective which is used is history from the bottom up, alongside certain theoretical and historiographical tenets from the work of Eric Hobsbawm. In the history of Split the time between 1918 and 1941 represents an era of expansion in great leaps and bounds in the fields of economy, demographics, culture, and so forth. The labouring classes of Split during this time experienced many shifts and changes from the time of the nineteenth century. A very wide effort in modernizing Split was undertaken by the urban elite, and the lower classes followed suit, sometimes purely by inertia, by changing their habits, customs and ways of engagement in society at large. This paper delves into the everyday lives - the labour, leisure, sporting activities - of craftsmen, peasants and working men and seeks to find commonalities and discrepancies which shaped their outlook. This outlook was particularly diverse when it came to the point of engaging with society and their seeking to bring about change, or remain on the same social plateau that they had acquired in the previous decades. Political shifts in the urban setting are also explored, and the parallel interwar shift towards mass democracy and other types of political activism (namely, the burgeoning and illegal communist movement) are marked as an essential turning point in the history of Split. Social sensibilities are defined through the utilization of contemporary newspaper souces and the existing historiographical literature.

Keywords: Split, interwar history, social structures, class, working class, sport, history from the bottom up, Eric Hobsbawm

\section{$\cos$}

\section{Izvorna grada}

Hrvatski državni arhiv, Zagreb, fond 163, Banovina Hrvatska, Odjel za obrt, industriju i trgovinu

\section{Novine i časopisi}

Football: list za propagandu sporta u Splitu

Glas bankovnog činovništva u Dalmaciji

Hrvatski pomorac

Jadranski sport

Obrtnički vijesnik

Privrednička rijec

Radnički odjek: list radnika i siromašnih seljaka

Radnicko pravo: glasilo Glavnog strukovnog saveza

Radnik: sindikalno glasilo radničke klase za Dalmaciju 
Stanar: glasnik Udruge stanara i podstanara

Stanar: glasilo stanara i podstanara u Splitu

\section{Literatura}

David Brody, „The Old Labor History and the New: In Search of an American Working Class“, The Labor History Reader (ur. Daniel J. Leab), Champaign 1985., 1-27.

Marijan Buljan, „Splitski općinski izbori 1928. godine“, Historijski zbornik, 66/2013., br. 2, 329_ 364.

Stevo ĐurašKović, „Ideologija Organizacije jugoslavenskih nacionalista (Orjuna)“, Časopis za suvremenu povijest, 43/2011., br. 1, 225-247.

Mario Garber (ur.), Crveni „Split“, Split 1984.

Anita ErCEgović, Pučka arhitektura starih splitskih predgrada, Split 2002.

Eric Hoвsваwм, „Mass-Producing Traditions: Europe, 1870-1914“, The Invention of Tradition (ur. Eric Hobsbawm i Terence Ranger), London 2012., 263-308.

Eric Новsваwм, On History, London 2009.

Eric Новзвашм, Worlds of Labour, London 1984.

Zdravka Jelaska Marijan, Grad i ljudi: Split 1918.-1941., Zagreb 2009.

Duško KeČKemet, Split moje mladosti, Zagreb 2008.

Anatolij KudrJavcev, Ča je pusta Londra..., Split 1998.

Anatolij Kudrjavcev, U potrazi za izgubljenim Mediteranom, Split 2001.

Nenad Lovrić, Splitski razgovori, Zagreb - Split 2014.

Norka Machiedo Mladinić, Životni put Ive Tartaglie, Split 2001.

Bogdan Radica, Vječni Split, Zagreb 2002.

Branislav Radica, Novi Split: monografija grada Splita od 1918-1930 godine, Split 1931.

Miljenko Smoje, Velo misto. Prvi dil, Split 2004.

Tonći Šitin, „Stjepan Radić i Dalmacija (1918.-1928.)“, Radovi Zavoda povijesnih znanosti HAZU u Zadru, 42/2000., 431-478.

E. P. Thompson, The Making of the English Working Class, London 1992. 